\title{
Antimicrobial resistance in coagulase-negative staphylococci isolated from subclinical mastitis in Ettawa Crossbred goat (PE) in Yogyakarta, Indonesia
}

\author{
WIDODO SUWITO ${ }^{1, \bullet}$, WIDAGDO SRI NUGROHO ${ }^{2}$, AGNESIA ENDANG TRI HASTUTI WAHYUNI ${ }^{3}$, \\ BAMBANG SUMIARTO ${ }^{2, \vee \varphi}$ \\ ${ }^{1}$ Assessment Institute for Agricultural Technology of Yogyakarta. Jl. Stadion Maguwoharjo No. 22, Wedomartani, Ngemplak, Sleman 55584, \\ Yogyakarta, Indonesia. Tel./fax.: +62-274-447052, `email: widodosuwito6@gmail.com \\ ${ }^{2}$ Department of Veterinary Public Health, Faculty of Veterinary Medicine, Universitas Gadjah Mada. Jl. Fauna No. 2, Bulaksumur, Sleman 55281, \\ Yogyakarta, Indonesia. Tel./fax.: +62-274-560861, "email: b.sumiarto@gmail.com \\ ${ }^{3}$ Department of Microbiology, Faculty of Veterinary Medicine, Universitas Gadjah Mada. Jl. Fauna No. 2, Bulaksumur, Sleman 55281, Yogyakarta, \\ Indonesia
}

Manuscript received: 20 April 2021. Revision accepted: 27 May 2021.

\begin{abstract}
Suwito W, Nugroho WS, Wahyuni AETH, Sumiarto B. 2021. Antimicrobial resistance in coagulase-negative staphylococci isolated from subclinical mastitis in Ettawa Crossbred goat (PE) in Yogyakarta, Indonesia. Biodiversitas 22: 3418-3422. Subclinical mastitis (SCM) in Ettawa Crossbred Goat (PE) is most frequently caused by staphylococci with a significant reduction in milk yield. The aim of this study is to determine antimicrobial resistance patterns of coagulase-negative staphylococci (CoNS) from PE goat SCM. A total of 36 CoNS isolates originating from PE goat SCM were collected in semisolid tube use in this study. All CoNS isolates were further examined for antimicrobial susceptibility testing by the Kirby-Bauer disc diffusion method. Antibiotic susceptibility of CoNS isolated samples according to Clinical Laboratory Standards Institute (CLSI). The CoNS isolates showed the highest resistance rate against sulfamethoxazole (65\%), ampicillin (55.56\%), penicillin (45\%), cefoxitin $(33.33 \%)$, erythromycin (25\%), oxytetracycline $(20 \%)$, tetracycline $(15 \%)$, gentamicin and neomycin $(11.11 \%)$, while oxacillin was sensitive. The highest of multiple antimicrobials resistance observed $15 \%$ in ampicillin, penicillin and tetracycline, then 5-10\% in ampicillin, penicillin, erythromycin, tetracycline and oxytetracycline. The majority of CoNS in this study were resistant to sulfamethoxazole and then, followed by ampicillin, penicillin, cefoxitin, erythromycin, oxytetracycline, tetracycline, gentamicin and neomycin. In addition, most isolates were penicillin-resistant and multidrug-resistant (MDR).
\end{abstract}

Keywords: Antimicrobial, goat, staphylococci, subclinical mastitis

\section{INTRODUCTION}

Ettawa Crossbred Goat (PE) is the product of crossing Ettawah Goat of Jamanapari, India origin with local goat from Indonesia such as Kacang goat. Characteristically PE goat has a curved nose, horned, long ear drops up to $30 \mathrm{~cm}$, long leg feathers with stripe white and black color. The body height of buck PE reaches $90-127 \mathrm{~cm}$, while the body of doe PE is $76-92 \mathrm{~cm}$. The bodyweight of buck PE is 68$91 \mathrm{~kg}$. The average of milk production PE goat is 1340.00 $\pm 76.38 \mathrm{~mL} / \mathrm{head} /$ day (Suranindyah et al. 2018).

PE goat much more is found in Yogyakarta, especially in Sleman regency with a total 1.749 population. Sleman regency located at $100-2.500 \mathrm{~m}$ above sea level with a total area $57.428 \mathrm{ha}, 107^{\circ} 15^{\prime} 03^{\prime \prime}$ and $107^{\circ} 15$ '03" coordinate, $107^{\circ} 29^{\prime} 30^{\prime \prime}$ East Longitude (BT), $7^{\circ} 34$ '51" and 7047' 30' South Latitude (LS) (Government of Sleman 2013). Sleman regency has a tropical climate with a rainfall average of $16.1 \mathrm{~mm}$ and a maximum speed of wind of 5.92 knots and a minimum of 1.3 knots. Consequently, Sleman regency has humidity relative $95.1 \%$ with the temperature at $21.5-33.8^{\circ} \mathrm{C}$.

Subclinical mastitis (SCM) is responsible for diseases in milk yield decrease in dairy goat herds (Koop et al.
2010). Subclinical mastitis characterized by an increased number of somatic cell counts (SCC) in milk without inflammation of the udder and when tested by California Mastitis Test (CMT) agglutination occurred (Carla et al. 2015). The CMT, qualitative measurement of the SCC in milk, is a screening test for SCM. The principle of the CMT test is indirect detection of total SCC in milk (Persson and Olofsson 2011).

Staphylococci bacteria have been reported as a common pathogen group associated with SCM in dairy goats (Padhy et al. 2015). The staphylococci bacteria group that causes more SCM in goats is coagulase-negative staphylococci (CoNS) (Mishra et al. 2018). The SCM in dairy goat, CoNS makes up $44.7 \%$ to $95.9 \%$ of the isolated pathogens from milk samples and Staphylococcus aureus (S. aureus) is usually considered to have the greater pathogenicity, accounts from $4.1 \%$ to $18.0 \%$ of SCM agents (Virdis et al. 2010).

In Yogyakarta, SCM in PE goats is rarely diagnosed by veterinarians. It is caused that SCM in PE goat no clinical symptom and CMT test is rarely done by veterinarians. Administration antibiotic in PE goat given during dry period for reducing the incidence of SCM. The administration of antibiotics at the end of a lactation period 
will complement the above procedures and will contribute to improved mammary health for the forthcoming lactation period (Petridis and Fthenakis 2014).

Currently, in Yogyakarta, antibiotics are sold freely without the control of veterinarians. It causes the PE goat farmers to easily obtained the antibiotics and freely use them. Administration of antibiotics without paying attention to the right dose may lead to antibiotic resistance. Concomitant with the increased number of antibiotics sold freely in Yogyakarta, especially to PE goat farmers, the aim of this research is to determine antimicrobial resistance patterns of CoNS from PE goat SCM.

\section{MATERIALS AND METHODS}

\section{Animal ethical commission}

Letter of approval from the Animal Ethical Commission is not required in this study because of no invasive procedure in the PE goat.

\section{Collection of samples}

A total of 150 PE goat lactation from 25 PE goat farms located in individual and communal houses in Yogyakarta, Indonesia is using in this study. Samples of PE goat milk collected when the milking process in the morning. The PE goat milk samples were aseptically collected from the udder healthy PE goat that PE goat farmer property in Yogyakarta, Indonesia. Briefly, the teats were wiped with swabs soaked in $70 \%$ ethanol, and thereafter, few streams of milk were discarded. The CMT test PE goat has done in the farm location and then, $10-15 \mathrm{~mL}$ of milk was collected into a sterile tube, labeled, and immediately brought to the Veterinary Public Health, Faculty of Veterinary Medicine, UGM, Yogyakarta for bacteriological examination.

\section{Determination of SCM in PE goat}

The CMT is using in the determination of SCM in PE goat. Briefly, the CMT assay was done by mixing 3-4 $\mathrm{ml}$ of PE goat milk with equal volume CMT reagent and then circular motion. The PE goat was called SCM if CMT assay showed a score of +2 or +3 and occur the gel formation (Persson and Olofsson 2011).

\section{Bacteriological examination of milk samples}

Bacteriological examination was performed according to Bacteriological Analytical Manual (BAM 2011). Briefly, $0.01 \mathrm{~mL}$ of milk with CMT positive +2 and +3 were streaked onto a half of a Mannitol Salt Agar plate (MSA CM:005, Oxoid Ltd., Basingstoke, United Kingdom) and overnight incubation at $37^{\circ} \mathrm{C}$. The colony was confirmed by morphology, Gram staining, catalase, and tube coagulase test. CNS isolates were stored at Brain-Heart semi-solid medium (BHI CM:1135, Oxoid Ltd., Basingstoke, United Kingdom) with 15\% (wt/vol) glycerol at refrigerator until further identification.

\section{Antibiotic susceptibility}

An antibiotic susceptibility test was performed using the disc diffusion method (CLSI 2018). Pure cultures of isolates CNS from PE goat SCM were standardized to 0.5 CFUs/mL McFarland standard. Mueller Hinton Agar plate (MHA; CM:0037, Oxoid Ltd., Basingstoke, United Kingdom) were inoculated with standardized inoculums of the test organism. Ten antibiotics (Thermo Fisher Scientific, Oxoid Ltd) were used for the susceptibility test in this study. The antibiotic discs were used ampicillin (10 $\mu \mathrm{g})$, cefoxitin $(30 \mu \mathrm{g})$, erythromycin $(15 \mu \mathrm{g})$, gentamicin (10 $\mu \mathrm{g})$, neomycin $(30 \mu \mathrm{g})$, oxytetracycline $(30 \mu \mathrm{g})$, oxacillin $(5 \mu \mathrm{g})$, penicillin (10 IU), sulfamethoxazole (300 $\mu \mathrm{g})$ and tetracycline $(30 \mu \mathrm{g})$. The discs were placed on the Mueller Hinton Agar plate (MHA; CM:0337, Oxoid Ltd., Basingstoke, United Kingdom) surface. Zone of inhibition $(\mathrm{mm})$ produced by each disc antibiotic after overnight incubation at $37^{\circ} \mathrm{C}$ was measured and then compared with CLSI breakpoints (CLSI 2018).

\section{Data analysis}

Data obtained from the CMT test, bacteriological examination of milk samples and antibiotic susceptibility were analyzed by using SPSS 25.0 (SPSS Inc., Chicago, IL, USA).

\section{RESULTS AND DISCUSSION}

\section{Determination of SCM}

Determination of SCM in PE goat from in Yogyakarta based on CMT is presented in Table 1. The PE goat milk samples with CMT scores of 0 and +1 were considered as negative, while the samples with scores +2 and +3 were taken as positive. A total of 91 PE goat's milk were done a test by CMT and it showed that 54 samples were identified as SCM (59.34\%) and non-SCM in 37 samples (40.7\%).

Table 1. Determination of SCM in PE goat from Yogyakarta, Indonesia based on CMT

\begin{tabular}{lcc}
\hline \multirow{2}{*}{ Goat milk samples } & \multicolumn{2}{c}{ CMT assay } \\
\cline { 2 - 3 } & $(-)$ & $(\geq++)$ \\
\hline PE goat milk (n: 91$)$ & 37 & 54 \\
Total $(\%)$ & 40.7 & 59.3 \\
\hline Note: $(-)$ : Negative SCM; $(\geq++)$ : Positive SCM
\end{tabular}

Note: (-): Negative SCM; $(\geq++)$ : Positive SCM

Table 2. Isolation staphylococci from PE goat milk SCM

\begin{tabular}{lccc}
\hline \multirow{1}{*}{ Sample } & \multicolumn{3}{c}{ Isolation bacteria } \\
\cline { 2 - 4 } & $\begin{array}{c}\text { Staphylococci } \\
\text { Coa+ }\end{array}$ & $\begin{array}{c}\text { Staphylococci } \\
\text { Coa- }\end{array}$ & $\begin{array}{c}\text { Other } \\
\text { bacteria }\end{array}$ \\
\hline PE goat milk (n: 54) & 13 & 36 & 5 \\
Total (\%) & 24.1 & 66.7 & 9.2 \\
\hline
\end{tabular}


Table 3. Antibiotic susceptibility of CNS from PE goat SCM in Yogyakarta, Indonesia

\begin{tabular}{|c|c|c|c|c|}
\hline \multirow{2}{*}{ Antibiotics } & \multicolumn{3}{|c|}{ Number isolate (n: 36) } & \multirow{2}{*}{$\operatorname{MDR}(\%)$} \\
\hline & S (\%) & $\mathrm{R}(\%)$ & I (\%) & \\
\hline Ampicillin $(10 \mu \mathrm{g})^{*} \Delta$ & 44.44 & 55.56 & 0 & ${ }^{*} 15 ;{ }^{\Delta} 5-10$ \\
\hline Cefoxitin $(30 \mu \mathrm{g})$ & 87 & 12 & 1 & none \\
\hline Erythromycin $(15 \mu \mathrm{g})$ & 73 & 25 & 2 & ${ }^{\Delta} 5-10$ \\
\hline Gentamicin $(10 \mu \mathrm{g})$ & 88.89 & 11.11 & 0 & none \\
\hline Neomycin $(30 \mu \mathrm{g})$ & 87.89 & 11.11 & 1 & none \\
\hline Oxacillin $(5 \mu \mathrm{g})$ & 100 & 0 & 0 & none \\
\hline Oxytetracycline $(30 \mu \mathrm{g})$ & 79 & 20 & 1 & ${ }^{\Delta} 5-10$ \\
\hline Penicillin G $(10 \mathrm{IU})^{* \Delta}$ & 48 & 45 & 7 & ${ }^{*} 15 ;{ }^{\Delta} 5-10$ \\
\hline Sulfamethoxazole $(300 \mu \mathrm{g})$ & 32 & 65 & 3 & none \\
\hline Tetracycline $(30 \mu \mathrm{g})^{* \Delta}$ & 84 & 15 & 1 & $* 15 ;{ }^{\Delta} 5-10$ \\
\hline
\end{tabular}

Note: S: Susceptible, R: Resistant, I: Intermediate, MDR: Multidrug-resistant. *: multiple resistance penicillin G, ampicillin, and tetracycline. ${ }^{\Delta}$ : multiple resistance penicillin $\mathrm{G}$, ampicillin, tetracycline, erythromycin, and oxytetracycline

\section{Bacteriological examination}

Subclinical mastitis in PE goat milk was caused by staphylococci Coa + in 13 samples $(24.1 \%)$, Coa - in 36 samples $(66.7 \%)$ and the other 5 samples $(9.2 \%)$ were not associated with staphylococci is presented in Table 2 .

\section{Antibiotic susceptibility}

Ampicillin, penicillin $\mathrm{G}$, and sulfamethoxazole are antibiotics that presented a high level of resistance $55.56 \%$, $45 \%$, and $65 \%$, respectively, and they are presented in Table 3. Multiple resistance occurred in ampicillin, penicillin $\mathrm{G}$ and tetracycline $15 \%$, while in penicillin $\mathrm{G}$ and ampicillin are 5-10\%.

\section{Discussion}

Mastitis in PE goats is an important disease, and it is responsible for serious economic loss to PE goat farmers in Yogyakarta mainly encountered in PE goats in subclinical form. In goat with SCM cannot be diagnosed by general physical examination such as palpation (Lakshmi and Jayavardhanan 2016). It is making goat farmers in Yogyakarta rarely knowing with SCM in PE goat. Overall, the occurrence of SCM in PE goats in Yogyakarta was assessed as $59.34 \%$. This result is similar to that reported by Akter et al (2020). Some researchers reported that the prevalence of SCM in goats is $37.19 \%, 38 \%, 45.82 \%$, and 50\% (Islam et al. 2011; Pirzada et al. 2016; Zhao et al. 2015; Mahlangu et al. 2016). Many risk factors that affected the prevalence of SCM in goats such as milk production, age of goat, litter size, parity, body condition score (BCS), and weaning age (Margatho et al. 2019; Koop et al. 2010; Suwito et al. 2014). Prevalence SCM in Barbari and Jamunapari goats were found as $24.21 \%$ and $15.12 \%$, respectively (Mishra et al. 2018). Prevalence SCM among the breeds of goat may be attributed to the difference in genetic resistance, hygiene, milking practices, management systems, and technical knowledge of the investigators along with methods used for the diagnosis of the disease (Islam et al. 2011).

Isolation of the bacteria associated with SCM in PE goat helps in designing effective preventive and control strategies. In our study, CoNS were found to be the most prevalent bacteria in causing SCM in the PE goats in
Yogyakarta. This result is in agreement with other studies that CoNS is the majority causal agent SCM in dairy goats (Bourabah et al. 2013; Salaberry et al. 2015; Dore et al. 2016). Commonly, CoNS was detecting in SCM goat milk and CoNS is frequently causes persistent SCM infection for several months, even though during the dry period (Gabli et al. 2019). In DIY, PE goat was still traditionally milked by hand and risk for staphylococci contaminant. The CoNS are opportunists and adhere to metal devices to produce a protective biofilm (Limoli et al. 2015). A biofilm is bunch of bacteria that attached to surface with carbohydrate covered which produced by this bacteria. The ability to produce biofilm causes CoNS to persist in milking equipment as well as in the milker's hands, which serves as a major of source staphylococcal spread (Lee et al. 2014).

Sulfamethoxazole is rarely used in treatment SCM in PE goats in Yogyakarta than ampicillin and penicillin G, but it is high quite of resistance. It was possible that caused by a genetic mutation in the plasmid. Sulfamethoxazole is often carried along with tetracycline resistance in plasmids (Munita and Arias 2016). An interesting in isolate observation is that high isolate resistant and multi-drug resistance (MDR) toward tetracycline and trimethoprimsulfamethoxazole as reported in other studies, although these molecules are only occasionally used for treating mastitis (Saed and Ibrahim 2020). Staphylococci resistance to sulfamethoxazole is mediated by following five mechanisms such as permeability barrier or efflux pumps, naturally insensitive enzymes target, regulation changes in the enzymes target, change of mutational or recombinational in the enzymes target and acquired resistance by drug-resistant enzymes target (Munita and Arias 2016).

In our studies, resistance to penicillin and ampicillin are higher than the other countries such as Italy that it reached up to $12 \%$ (Virdis et al. 2010). Other researches were reported that resistance $S$. aureus toward penicillin in clinical mastitis (CM) and SCM at goat in Malaysia is 22\% (Ariffin et al. 2019). The difference of resistance to antibiotics among the others countries is possibly be affected by some factors such as management in the farm, especially intensity application antibiotic. Carelessly and limitation PE goat farmers in using antibiotic is potential to 
resistance. Penicillin and ampicillin are antibiotics that destroy the wall cell of Gram-positive bacteria (Munita and Arias 2016). The chemical structure of penicillin has a ring beta-lactam, whereas ampicillin is a derivative of penicillin. Resistance to penicillin and ampicillin in CoNS from PE goat SCM in Yogyakarta may be caused by produce beta-lactamase enzyme and destroy the ring betalactam. Consequently, it was required to substitute antibiotics such as oxacillin or cefoxitin.

The MDR isolate is a condition of bacterial isolate that is resistant to antibiotics at least $\geq 2$ antibiotic groups (CLSI 2018). The MDR was discovered in CoNS from PE goat SCM in Yogyakarta about 5-15\%. It was discovered in ampicillin, penicillin, and tetracycline (15\%) and ampicillin, penicillin, erythromycin, tetracycline, and oxytetracycline (5-10\%). The occurrence of MDR in PE goat in Yogyakarta is lower than in other countries which reached up to $44.4-73.86 \%$ (Ceniti et al. 2017). The majority of SCM at the cow in Uganda was caused by $S$. aureus and $71 \%$ showed MDR (Kasozi et al. 2014). Occurrence differences of MDR in CoNS isolate were caused by some factors such as antibiotic utilization in the PE goat farms. Penicillin, ampicillin, tetracycline, and oxytetracycline are widely used antibiotic in PE goat farms in Yogyakarta because it is easily and freely available for sale. Consequently, antimicrobial resistance (AMR) in ampicillin, penicillin $\mathrm{G}$, tetracycline, and oxytetracycline much more occur than with other antibiotics. The AMR was caused by mutations protein on active site receptor that recognizes antibiotic and formation of plasmids that encode gene resistance to several antibiotics (Munita and Arias 2016). Plasmids are extrachromosomal deoxyribose nucleic acid (DNA), while episome is a plasmid that bounded at extrachromosomal DNA. R-plasmid is responsible for antibiotic resistance. R-plasmid consists of 2 units, namely Resistance Transfer Factor (RTF) segment and determinant-r (unit-r). The RTF segment is responsible for moving of R-plasmid, whereas unit-r is carried with properties antibiotic resistance (Munita and Arias 2016).

Occurrence of MDR in CoNS toward penicillin or ampicillin caused by staphylococci produces $\beta$-lactamase and destroys the structure of ring $\beta$-lactam at penicillin. Staphylococci with MDR are known as methicillinresistant S. aureus (MRSA) and generally, the bacteria were resistant to $\beta$-lactam antibiotics. The MRSA was formed of substitution in gen that Penicillin Binding Protein (PBP2) encoding to PBP2a, so that active side receptors for $\beta$-lactam antibiotic cannot be recognized (Genovese et al. 2021). Antibiotic resistance occurred to change in the active side of amino acids into the other amino acid which occurs at several points, for example at position 106 serine change to amino acid glycine, serine 70 change to alanine and serine 42 change to asparagine (Munita and Arias 2016).

The majority of CoNS in this study were resistant to sulfamethoxazole and then, followed by ampicillin, penicillin, cefoxitin, erythromycin, oxytetracycline, tetracycline, gentamicin and neomycin. In addition, most isolates were penicillin-resistant and MDR.

\section{ACKNOWLEDGEMENTS}

The authors would like to thank the association of PE Goat farmers in DIY for allowing the sample PE goat milk from their herds. Technical assistance in laboratory Veterinary Public Health and Microbiology, Gadjah Mada University, Sunarto, Laila Nurfatima and Sri Hartini is highly appreciated.

\section{REFERENCES}

Akter S, Rahman M, Sayeed A, Islam Md N, Hoque Md A, Koop G. 2020. Prevalence, aetiology and risk factors of subclinical mastitis in goats in Bangladesh. Small Rumin Res 184: 1060-1064. DOI: 10.1016/j.smallrumres.2020.106046.

Ariffin S, Hasmadi MZN, Syawari NM, Sukiman MZ, Ariffin MFT, Hian CM, Ghazali MF. 2019. Prevalence and antibiotic susceptibility pattern of Staphylococcus aureus, Streptococcus agalactiae and Escherichia coli in Dairy Goats with clinical and subclinical mastitis. J Anim Health Prod 7 (1): 32-37. DOI; 10.17582/journal.jahp/2019/7.1.32.37.

Bacterial Analytical Manual (BAM). 2011. Chapter 12 Staphylococcus aureus in foods. In Food and Drug Administration. http://www.fda.gov, [10 February 2013].

Bourabah A, Ayad A, Boukraa L, Hammoudi S, Benbarek H. 2013. Prevalence and etiology of subclinical mastitis in goats of the Tiaret Region, Algeria. Glob Vet 11 (5): 604-608.

Carla MD, Paulo PF, Bexiga R. 2015. Technological advances in bovine mastitis diagnosis: an overview. J Vet Diagn Invest 27 (6): 665-672. DOI: $10.1177 / 1040638715603087$.

Ceniti C, Britti D, Santoro AML, Musarella R, Ciambrone L, Casalinuovo F, Costanzo N. 2017. Phenotypic antimicrobial resistance profile of isolates causing clinical mastitis in dairy animals. Italian J Food Saf 6612 (6): 84-87.

Clinical and Laboratory Standards Institute (CLSI). 2018. Performance standards for antimicrobial disk susceptibility tests; approved standard-12th ed. Clinical and Laboratory Standards Institute, Wayne, PA.

Dore S, Liciardi M, Amatiste S. 2016. Survey on small ruminant bacterial mastitis in Italy, 2013-2014. Small Rumin Res 141: 91-93. DOI: 10.1016/j.smallrumres.2016.07.010.

Gabli Z, Djerrou Z, Gabli AE, Bensalem M. 2019. Prevalence of mastitis in dairy goat farms in Eastern Algeria. Vet World 12 (10): 1563-1572. DOI: 10.14202/vetworld.2019.1563-1572.

Genovese C, D'Angeli F, Bellia F, Distefano A, Spampinato M, Attanasio F, Nicolosi D, Di Salvatore V, Tempera G, Furno DL, Mannino G, Milardo F, Volti G. 2021. In vitro antibacterial, anti-adhesive and anti-biofilm activities of Krameria lappacea (Dombey) Burdet \& B.B. Simpson Root Extract against Methicillin-Resistant Staphylococcus $\begin{array}{llll}\text { aureus } & \text { strains. Antibiotics } 10 & \text { (428): 1-21. DOI: }\end{array}$ 10.3390/antibiotics10040428.

Government of Sleman. RKPD Kabupaten Sleman Tahun 2014 (in Indonesia). Available at: http://bappeda. slemankab.go.id/wpcontent/uploads/2013/07/bab-II.pdf, accessed 18 January 2021.

Islam MA, Samad MA, Rahman AKMA. 2011. Bacterial pathogens and risk factors associated with mastitis in Black Bengal Goats in Bangladesh. Bangl J Vet Med 9 (2): 155-159. DOI: 10.3329/bjvm.v9i2.13458.

Kasozi KI, Tigiira JB, Vudriko P. 2014. High prevalence of subclinical mastitis multidrug-resistant Staphylococcus aureus are a threat to dairy cattle production in Kibota District (Uganda). J Vet Med 4: 3543. DOI: $10.4236 /$ ojvm.2014.44005.

Koop G, Werven T.van, Schuilling HJ, Nielen M. 2010. The effect of subclinical mastitis on milk yield in dairy goats. J Dairy Sci 93 (12): 5809-5817. DOI: 10.3168/jds.2010-3544.

Lakshmi K, Jayavardhanan K. 2016. Screening of milk samples for subclinical and clinical mastitis by using CMT and SCC. J Med Sci Clin Res 4: 10853-10855. DOI: 10.18535/jmscr/v4i6.27.

Lee SHI, Mangolin BLC, Gonçalves JL, Neeff DV, Silva MP, Cruz AG, Oliveira CAF. 2014. Biofilm-producing ability of Staphylococcus 
aureus isolates from Brazilian dairy farms. J Dairy Sci 97 (3): 18121816. DOI: $10.3168 /$ jds.2013-7387.

Limoli DH, Jones CJ, Wozniak DJ. 2015. Bacterial extracellula polysaccharides in biofilm formation and function. Microbiol Spectr 3 (3): 1-30. DOI: 10.1128/microbiolspec.MB-0011-2014.

Mahlangu P, Maina N, Kagira J. 2016. Prevalence, risk factors, and antibiogram of bacteria isolated from milk of goats with subclinical mastitis in Thika East Sub-county, Kenya. J Vet Med 11 (2): 1-8 DOI: $10.1155 / 2018 / 3801479$

Margatho G, Estévez VR, Quintas H, Simões J. 2019. The effects of reproductive disorders, parity, and litter size on milk yield of Serrana goats. Animals 9 (968): 1-11. DOI: 10.3390/ani9110968.

Mishra AK, Sharma N, Singh DD, Guruaj K, Abhishek, Kumar V, Sharma DK. 2018. Prevalence and bacterial etiology of subclinical mastitis in goats reared in organized farms. Vet World 11 (1): 20-24 DOI: $10.14202 /$ vetworld.2018.20-24.

Munita JM, Arias CA. 2016. Mechanisms of antibiotic resistance. Microbiol Spectr 4 (2): 1-37. DOI: 10.1128/microbiolspec.VMBF0016-2015.

Padhy A, Sahu AR, Shekhar S, Sahoo S, Sahoo A, Dalai N. 2015. Staphylococcus aureus: An emergent cause of bovine mastitis in India-a review. Int J Livest Res 5 (2): 1-7. DOI: 10.5455/ijlr.20150212093551.

Persson Y, Olofsson I. 2011. Direct and indirect measurement of somatic cell count as indicator of intramammary infection in dairy goats. Acta Vet Scand 53 (1): 1-15. DOI: 10.1186/1751-0147-53-15.

Petridis IK, Fthenakis GC. 2014. Administration of antibiotics to ewes at the beginning of the dry period. J Dairy Res 81 (1): 9-15. DOI: $10.1017 /$ S0022029913000472.
Pirzada M, Malhi KK, Kamboh AA, Rind R, Abro SH, Lakho SA, Bhutto K ur R, Huda ul N. 2016. Prevalence of subclinical mastitis in Dairy Goats caused by bacterial species. J Anim Health Prod 4 (2): 55-59. DOI: $10.14737 /$ journal.jahp/2016/4.2.55.59.

Saed HAEMR, Ibrahim HMM. 2020. Antimicrobial profile of multidrugresistant Streptococcus spp. isolated from dairy cows with clinical mastitis. J Adv Vet Anim Res 7 (2): 186-197. DOI: 10.5455/javar.2020.g409.

Salaberry SR, Saidenberg AB, Zuniga E. 2015. Virulence factors genes of Staphylococcus spp. isolated from caprine subclinical mastitis. Microb Pathog 85: 35-39. DOI: 10.1016/j.micpath.2015.05.007.

Suranindyah YY, Khairy DHA, Firdaus N, Rochijan. 2018. Milk production and composition of Ettawah Crossbred, Sapera and Saperong Dairy Goats in Yogyakarta, Indonesia. Int J Dairy Sci 13 (1): 1-6. DOI: 10.3923/ijds.2018.1.6.

Suwito S, Nugroho WS, Sumiarto B, Wahyuni AETH. 2014. Faktorfaktor risiko mastitis subklinis pada kambing Peranakan Etawah di kabupaten Sleman, Yogyakarta. Jurnal Veteriner 15 (1): 130-138. [Indonesian]

Virdis SC, Scarano F, Cossu V, Spanu C, Spanu, de Santis EPL. 2010. Antibiotic resistance in Staphylococcus aureus and coagulasenegative Staphylococci isolated from goats with subclinical mastitis. Vet Med Int 7 (1): 1-7. DOI: 10.4061/2010/517060.

Zhao Y, Liu H, Zhao X, Gao Y, Zhang M, Chen D. 2015. Prevalence and pathogens of subclinical mastitis in dairy goats in China. Trop Anim Health Prod 47 (2): 429-435. DOI: 10.1007/s11250-014-0742-y. 